\title{
Increasing Self-Efficacy of Middle School Emergent Bilingual Students
}

\author{
Lisa Rose Johnson \\ The University of Alabama in Huntsville
}

\begin{abstract}
The goal of this quasi-experimental study completed by a teacher-researcher was to determine how students use their second language (L2) to advocate for themselves in classroom settings. The participants included $(n=10)$ middle school emergent bilingual students and their ESL teacher. The teacher collected data using the General Self-Efficacy Scale and fifteen strategies from the Self-Efficacy Toolkit that is found on the Transforming Education website. The student participants also completed oral and written tasks that were scored using the WIDA Speaking and Writing Interpretive Rubric. The student performance tasks were aligned with the WIDA Can Do Descriptors. The results revealed that middle school ESL students can increase their self-efficacy as a result of direct instruction.
\end{abstract}

Keywords: emergent bilinguals, middle grades, self-efficacy, teacher-researcher, transforming education self-efficacy toolkit

\section{INTRODUCTION}

The purpose of this study was to increase self-efficacy skills in middle school students enrolled in a pull-out ESL program. Currently, the classroom textbooks available to the researcher did not include strategies and skills related to teaching self-efficacy. Many times, emergent bilingual students do not have the proper vocabulary skills to ask for help. This prohibits the students from explaining what they need to be successful. Observations from the teacher revealed that students also lack confidence when communicating about weaknesses in their second language (L2). This study implemented fifteen suggested strategies from the Transforming Education Self-Efficacy Toolkit. This toolkit is free and can be accessed from the following website, https://www.transformingeducation.org/self-efficacy-toolkit/.

\section{What Is Self-Efficacy?}

Self-efficacy is important to all learners and is a skill that often needs to be taught explicitly (Margolis \& McCabe 2006, Schunk, \& Hanson, 1985). There are many programs designed to teach self-efficacy to students with disabilities. Self-efficacy is often linked to Individual Education Plans and transition planning goals. Self-efficacy refers to an individual's belief in his or her capacity to execute behaviors necessary to produce performance specific skills (Bandura, 1977, 1981, 1982). Further self-efficacy reflects confidence in the ability to exert control. This control can be over a person's own motivation, behavior, and social environment. Individuals who can complete cognitive self-evaluations influence all manner of human experiences. These experiences can include personal goals, and the amount of energy expended toward achieving a goal. (Teaching Tip Sheet Self-Efficacy, 2009). 


\section{Conceptual Framework: The Effectiveness of Teaching Self Efficacy}

This project began when the teacher-researcher was looking for free research-based materials that took promoting social emotional learning to the next level. Prior to the study the teacher had relied on resources from Denton \& Kriete (2000) on implementing morning meetings and other activities to promote inclusion while addressing social emotional learning. The First Six Weeks of School is a book written by Denton \& Kriete that was published in the year 2000. This book takes classroom management to the next level. The book focuses on four intentions also known as prime factors. These prime factors included first, creating a climate and tone of warmth and safety. Second, teach the schedule and routines of the school day and the expectations of behavior in each of them. The third factor is to introduce students to the physical environment and materials of the classroom and the school, while teaching students how to use and care for them. The fourth intention is to establish expectations about ways we will learn together in the year ahead (Denton \& Kriete 2000). While these pillars intentions were a part of the classroom, the teacher felt that this was not enough to meet the needs of the students. The teacher-researcher used observations and reflections to determine that one problem that middle school emergent bilingual students demonstrated was that students did not feel comfortable communicating with subject area teachers. All too often the students would expect the ESL teacher to solve their problems.

The subject area teachers and the ESL teacher wanted the students to gain competencies in both the academic language and their social language while gaining the self-confidence needed to ask for help. After an extensive search for effective strategies using Google Scholar the Transforming Education Self-Efficacy Toolkit was selected in part for its clarity and accessibility and that it was designed for middle grade students. Additional factors for selecting this toolkit included that it was the highest searched toolkit using the Google Scholar search engine and that it was free to download. The teacher-researcher also had an interest to see if these suggested strategies would allow for emergent bilingual students to improve their self-efficacy even though emergent bilingual students were not the sole intended audience. The toolkit also allowed for a roadmap for college to be developed. This road map may become a helpful tool because many of the students' families lack a college education. The transforming education website did not provide any guidance specifically related to emergent bilinguals, so the ESL teacher adapted and developed assignments to teach the suggested strategies for middle school emergent bilingual students.

\section{Providing Instruction on the Fifteen Strategies}

The instruction of the strategies was delivered using direct instruction and small group peer instruction. The toolkit presents 15 strategies. Additional data was collected from the administration of the General Self-Efficacy Scale (GSE) the pretest and posttest were administered 15 weeks apart. Table 1 Classroom and Generalization Strategies to Build Self-Efficacy lists the strategies that were included in the lessons. Six of the activities $(4,9,11,13,14,15)$ were reliant on teacher data accountability while the remaining seven strategies collected data based on student work samples $(2,3,5,6,7,8,10,12)$. Activities one and seventeen were the administration of the pretest and posttest of the GSE. The emergent bilingual student participants varied by their gender, ethnicity, first language, and the amount of time that they had spent in the United States. The mixed method analysis of data collected included student work samples, observations, and teacher-created rubrics. The World Class Instructional Design and Assessment (WIDA) Speaking and Writing Interpretive Rubrics and the Can Do Descriptors were also used as a progress monitoring tool to show growth of English proficiency.

\section{Review of the Literature}

The review of the literature revealed that many scholars agree that teaching self-efficacy is important (Margolis \& McCabe 2006; Schunk, \& Hanson, 1985). The Transforming Education Self-Efficacy Toolkit provides the basic definition of self-efficacy stating that it is the belief in one's ability to succeed in achieving an outcome or reaching a goal. This belief, specific to a task or an area of knowledge or performance, shapes the behaviors and strategies that help one pursue their goal. High self-efficacy reflects confidence in the ability to exert control over one's own motivation, behavior, and environment, while allowing students to become advocates for their own needs and supports (Bandura, 1977, 1981, 1982; 
Teaching Tip Sheet-Self-Efficacy, 2009). Research suggests that self-efficacy can boost student achievement, foster emotional health and well-being, and serve as a valid predictor of motivation and learning. Studies also have shown that students with high levels of self-efficacy participate more in class, work harder, persist longer, and have fewer adverse emotional reactions when encountering difficulties when compared to students who lack effective self-efficacy skills (Self Efficacy Toolkit, n. d.).

Currently, there is no direct research on increasing self-efficacy in middle school emergent bilingual students. One method to teach self-efficacy is to have students engage in peer modeling (Margolis \& McCabe 2006; Schunk, \& Hanson, 1985). This peer modeling was observed in Science Technology Engineering and Math (STEM) activities. Past research from Brophy, Klein, Portsmore \& Rogers (2008) provided guidance on the benefits of STEM. Brophy et al., (2008) described many educational benefits of engineering education and how it allows for students to practice and acquire critical thinking and the ability to solve problems. Students who are enrolled in STEM or engineering classes had an increased rate of comprehending and accomplishing real-world problem solving through design, troubleshooting, and analysis activities. These skills increase critical thinking and confidence which is aligned with building selfefficacy. English (2017) stated the benefits of these programs, that allow for critical thinking. There is little research in the area of the benefits of STEM/STEAM programs for students who are enrolled in ESL programs but there have been longitudinal studies for self-efficacy using the general self-efficacy scale and a diverse population (Luszczynska, Scholz, \& Schwarzer, 2010). Luszczynska, Scholz, \& Schwarzer (2010) presented data collected from 1,933 respondents in 3 countries: Germany $(n=633)$, Poland $(n=359)$, South Korea $(n=941)$. Participants were between the ages of 16 and 86 years old and all completed the General Self-Efficacy Scale. This scale was given to all of the participants as a pretest and posttest. Although this study focused on adults it is related as it shows the importance of gaining self-efficacy skills to ensure success as an adult.

\section{Research Questions}

Three research questions guided this study. All three research questions allowed students to show growth and progress within their Level of English Proficiency on the WIDA Rubrics and WIDA Can Do Descriptors that are as follows: Can middle school emergent bilinguals/second language learners (L2) increase self-efficacy as a result of a direct instruction unit? Will students' verbal, and written scores increase when scored using the WIDA Speaking and Writing Interpretive Rubric over the course of the 15week program? Will students mimic what is used by their peer models to advocate for themselves when they do not understand what to do on an assignment or in class?

\section{Participants}

This study collected data from one teacher and ten middle school emergent bilingual students enrolled in a pull-out classroom in a Middle Atlantic state that is part of the WIDA Consortium. The students included one teacher with over ten years of experience as a classroom ESL teacher and $(n=10)$ students. Utilizing the WIDA rubrics to score data enabled the teacher-researcher to engage in progress monitoring of student growth with regard to the WIDA standards. This is essential as the Rubrics are created to assess students who are gaining English Proficiency specifically. Furthermore, the WIDA rubrics and the Can Do Descriptors allow the students to understand what is expected concerning their performance on the WIDA Access 2.0 Assessment. States within the WIDA Consortium use this assessment to determine if emergent bilingual students meet the state level criteria to be exited from ESL services.

\section{Research Methods}

The teacher and student participants $(\mathrm{n}=10)$ were selected from a middle school in the Middle Atlantic region of the United States. Some of the activities were modified to be oral only based on the student's English Score on the WIDA Model Screener or WIDA ACCESS 2.0 test from the prior year of school. The data was collected using a teacher created handout for students and a Teacher Worksheet for feedback. Data was collected using the packets. Students also used Flipgrid to record videos that were scored by the teacher. 
The videos were transcribed for grammatical accuracy based on what was expected at their level of English proficiency using the WIDA rubrics and Can Do Descriptors. Additionally, having the students record videos allowed students to demonstrate their ability to show what words they used to ask for help documenting if their self-efficacy skills were growing through the direct instruction of the strategies. The videos also showed evidence of the students explaining what they understood in their own words. At the end of each lesson, both the oral and written expressive output rubrics developed by WIDA were used to score the students speaking and writing. Using these rubrics allowed the teacher to show progress with the WIDA standards. This was important because all student participants were required to complete the WIDA ACCESS 2.0 Assessment in March of that school year to show growth. Table 1 below reveals the order of the strategies that were taught to the student participants.

\section{TABLE 1 CLASSROOM AND GENERALIZATION STRATEGIES TO BUILD SELF-EFFICACY}

1. (Pretest) Administer the General Self Efficacy Scale (GSE) in English and if available in their native language if they preferred that option for baseline data collection.

\section{Classroom Strategies for the Toolkit Supplemental Handout}

2. Develop learning progressions with your students' progression — a roadmap towards the mastery of a skill or task - that clearly represents expectations at different stages of achievement. This can help students track their progress towards the mastery of a skill or content-area.

3. Use peer models for learners to observe others who are working through or have mastered a similar challenge and are modeling an effective strategy.

4. Provide specific feedback that reflects what is driving the student's performance (e.g, strategy, effort, etc.).

5. Guide students through imagining themselves as confident and successful in a specific (and perhaps, stressful) situation using If/Then statements.

6. Have students practice building awareness about their feelings and sensations through exercises such as mindfulness.

7. Encourage students to reframe their stress into a mindset of excitement and anticipation.

Additional generalized strategies. How can the following generalized strategies help you foster your students' high self-efficacy?

8. Make successful events more likely and more frequent by setting small, attainable goals and subgoals for learning. This allows students to experience success regularly and gradually in the subject matter.

9. Continuously support students' coping strategies, which can involve providing ongoing support to help them navigate setbacks, work through different problems, and try new and different strategies.

10. Teach specific learning strategies and help students practice using these strategies. This involves identifying a few critical strategies that the student can practice and master, and then helping the student learn when and why to use the strategy effectively and on their own.

11. Reinforce students' effort, persistence, and effective use of learning strategies to motivate students to use these strategies in the future.

12. Leverage student choice and interest to boost student motivation and engagement. For example, allow students to choose books, break times, and extra credit work that are meaningful to them and acceptable to the teacher. 
13. Encourage students to try new academic activities at appropriate instructional and independent levels. This can provide students with opportunities to learn that moderate effort can produce success, even in areas they didn't realize.

14. Remind students of recent, similar successes in related subject areas or tasks. This can help students acknowledge their previous successes, building upon their mastery experience.

15. Give frequent, focused, task-specific feedback to help students learn what they are doing correctly and how they can improve, thus helping them create a framework or blueprint for success.

16. Create opportunities for self-efficacy beliefs to generalize across situations, allowing one set of experiences to influence the next

17. (posttest) Administer the General Self Efficacy Scale (GSE) in English and if available in their native language if they preferred that option for comparison to the base line data results.

Strategies from Self-Efficacy Supplemental Hand Out (n.d.)

\section{Findings}

Each activity/lesson was scored based on the completion of the activity. The output was used for classwork grades related to language. The final project was graded as a presentation grade and was shared with the STEM staff. As for point deductions and lower scores, students who did not follow directions or chose not to complete the assignment were not given full credit. The overall analysis used the percentages of students who completed the activities and met the benchmark of the Rubric within their WIDA level. This allowed for students to be scored based on their language ability so that students who were at the lower levels of proficiency were not penalized. Table two shows the percentage of students who completed the thirteen activities.

Further analysis revealed that the research questions could be successfully answered. To answer the first question, "Can middle school emergent bilinguals/second language learners (L2) increase self-efficacy as a result of a direct instruction unit?" It was determined that all of the participants $(n=10)$ did increase their self-efficacy as a result of the lessons. Student Performance on the GSE also showed growth when comparing the pre and post assessments. The analysis revealed that after each lesson was taught, the students participated more fully and increased their language output when completing the activities. Students also asked if they could attend study sessions and tutorials with subject matter teachers. The students were also able to ask for examples and could answer questions in peer study sessions. This was also aligned with Schunk, \& Hanson (1985) and Margolis \& McCabe (2006) who observed that students who had peer models acquired higher self-efficacy for learning. Students who had access to peer models also scored higher on a posttest for self-efficacy, and demonstrated a higher achievement compared to students who observed the teacher model or did not have a model to observe. Schunk \& Hanson (1985) also reported that students who observed the teacher model scored higher than students who did not have a model to observe during the activities that were part of the study.

The second research question, "Will students' verbal, and written scores increase when scored using the WIDA Speaking and Writing Interpretive Rubric over the course of the 15-week program?" For the most part, students who were scored using the Developing Level 3 criteria did sometimes produce enough output to move up to Level 4, the Expanding Level based on the rubrics and the expectations of the Can Do Descriptors. These students also demonstrated growth with spelling and other areas of language acquisition that are most likely unrelated to this project. Perhaps these gains are a result of good teaching strategies and consistency with other academic programs that are used in the classroom. In general, students did show growth and made some gains to a higher WIDA level, but those gains are built over time and again may not be linked to the strategies that were taught to build self-efficacy. Also, it is important to understand there is some fluidity that exists with language acquisition (Nippold, 2000). As students demonstrate academic growth, they are likely to produce work samples at multiple levels within the WIDA Rubric and Can Do 
Descriptors as their academic skills grow during the school year. In the future, more research is needed to develop and test activities to determine how the strategies are directly supporting the acquisition of literacy skills in English.

The third research question asked, "Will students mimic what is used by their peer models to advocate for themselves when they do not understand what to do on an assignment or in class?" This question was also successfully answered. The data revealed that $100 \%(\mathrm{n}=10)$ of the students were able to complete the final PowerPoint presentations and to use the models that were created by the teacher. The students also used Flipgrid to give peer feedback and were able to use the sentence starters used by their peers who had more advanced English skills. Additionally, the student videos gave the students opportunities to improve their reading, writing, speaking, and listening skills as well as their presentation skills.

DATA RESULTS OF THE 17 STRATEGIES

\begin{tabular}{|c|c|c|c|}
\hline Activities & $\begin{array}{l}\text { Student Accountability } \\
\text { Percentage of students } \\
\text { who could complete } \\
\text { the act orally }\end{array}$ & $\begin{array}{l}\text { Student Accountability } \\
\text { Percentage of students } \\
\text { who could complete the } \\
\text { act using written } \\
\text { communication }\end{array}$ & $\begin{array}{l}\text { Teacher } \\
\text { Accountability }\end{array}$ \\
\hline $\begin{array}{l}\text { Pretest Activity 1: } \\
\text { Give the General Self-Scale } \\
\text { in English and the Native } \\
\text { Language }\end{array}$ & $\begin{array}{l}10 / 10 \text { completed the } \\
\text { scale }\end{array}$ & $10 / 10$ & \\
\hline $\begin{array}{l}\text { Activity 2: Roadmap for } \\
\text { success }\end{array}$ & $\begin{array}{l}10 / 10 \text { were able to tell } \\
\text { me their plan was to } \\
\text { attend college orally. }\end{array}$ & $\begin{array}{l}7 / 1070 \% \\
\text { One student was port of } \\
\text { entry and wrote the } \\
\text { responses in Chinese } \\
\text { and translated them, } 2 \\
\text { students did not } \\
\text { complete activity }\end{array}$ & \\
\hline Activity 3: Peer models & $\begin{array}{l}10 / 10 \text { were able to } \\
\text { restate a peer's plan } \\
\text { for the future. }\end{array}$ & $\begin{array}{l}7 / 10 \text { One student was } \\
\text { port of entry and wrote } \\
\text { the responses in } \\
\text { Chinese and translated } \\
\text { them, } 2 \text { students did not } \\
\text { complete writing } \\
\text { activity for the peer's } \\
\text { future job. }\end{array}$ & \\
\hline $\begin{array}{l}\text { Activity 4: Provide specific } \\
\text { feedback }\end{array}$ & Teacher data & Teacher data & $\begin{array}{l}\text { Teacher gives } \\
\text { feedback to } 10 / 10 \\
\text { students }\end{array}$ \\
\hline $\begin{array}{l}\text { Activity 5: Guide students } \\
\text { through imagining } \\
\text { themselves as confident and } \\
\text { successful }\end{array}$ & $\begin{array}{l}10 / 10 \text { students orally } \\
\text { completed the if/then } \\
\text { statements with a } \\
\text { partner }\end{array}$ & $\begin{array}{l}10 / 10 \text { students } \\
\text { completed the if/then } \\
\text { frames and recorded } \\
\text { their flip grid }\end{array}$ & \\
\hline $\begin{array}{l}\text { Activity 6: ( } 30 \text { min. Body } \\
\text { Scan) Student's practice } \\
\text { building awareness about } \\
\text { their feelings and sensations }\end{array}$ & $\begin{array}{l}10 / 10 \text { students } \\
\text { completed an informal } \\
\text { thumbs up thumb } \\
\text { down about how they } \\
\text { felt following the }\end{array}$ & $\begin{array}{l}10 / 10 \text { Students used } \\
\text { sentence frames to } \\
\text { describe how they felt } \\
\text { that day. }\end{array}$ & \\
\hline
\end{tabular}




\begin{tabular}{|c|c|c|c|}
\hline $\begin{array}{l}\text { through exercises such as } \\
\text { mindfulness }\end{array}$ & $\begin{array}{l}\text { activity. They also } \\
\text { selected an emoji for } \\
\text { how they felt at that } \\
\text { moment both before } \\
\text { and after the exercise. }\end{array}$ & & \\
\hline $\begin{array}{l}\text { Activity } 7: \text { Encourage } \\
\text { students to reframe their } \\
\text { stress into a mindset of } \\
\text { excitement and anticipation } \\
\text { and learn to read their body } \\
\text { and ask themselves what I } \\
\text { am feeling? Why and I } \\
\text { feeling this way? }\end{array}$ & $\begin{array}{l}10 / 10 \text { students could } \\
\text { express how they felt } \\
\text { in the moment. } \\
\text { Through body } \\
\text { scanning and breathing } \\
\text { they could express } \\
\text { how they feel. }\end{array}$ & $\begin{array}{l}10 / 10 \text { students could } \\
\text { complete sentence } \\
\text { frames to express how } \\
\text { they felt in the moment. } \\
\text { They could write how } \\
\text { body scanning helped } \\
\text { them to know how they } \\
\text { were feeling. }\end{array}$ & r \\
\hline $\begin{array}{l}\text { Activity } 8 \text { : Set small, } \\
\text { attainable goals and sub- } \\
\text { goals for learning. This } \\
\text { allows students to } \\
\text { experience success regularly } \\
\text { and gradually in the subject } \\
\text { matter }\end{array}$ & $\begin{array}{l}10 / 10 \text { students were } \\
\text { able to state a goal }\end{array}$ & $\begin{array}{l}10 / 10 \text { were able to write } \\
\text { a goal using I will } \\
\text { statement }\end{array}$ & \\
\hline $\begin{array}{l}\text { Activity 9: Continuously } \\
\text { support students' coping } \\
\text { strategies, which can } \\
\text { involve providing ongoing } \\
\text { support to help them } \\
\text { navigate setbacks, work } \\
\text { through different problems, } \\
\text { and try new and different } \\
\text { strategies. }\end{array}$ & Teacher data & Teacher data & $\begin{array}{l}\text { Teacher meets with } \\
\text { students weekly } \\
\text { individually to } \\
\text { provide support } \\
\text { and to review } \\
\text { goals. Data is } \\
\text { collected in a } \\
\text { shared journal }\end{array}$ \\
\hline $\begin{array}{l}\text { Activity 10: Teach } \\
\text { strategies involves } \\
\text { identifying a few critical } \\
\text { strategies that the student } \\
\text { can practice and master, and } \\
\text { then helping the student } \\
\text { learn when and why to use } \\
\text { the strategy effectively and } \\
\text { on their own. ( } 4 \text { did } \\
\text { multiplication skills and } \\
\text { drill and } 6 \text { did balancing } \\
\text { chemical equations }\end{array}$ & $\begin{array}{l}3 / 4 \text { showed growth in } \\
\text { learning multiplication } \\
\text { skills by completing a } \\
100 \text {-question } \\
\text { worksheet in under } \\
\text { five minutes ( } 5 \text {-minute } \\
\text { frenzy) } \\
6 / 6 \text { learned how to } \\
\text { successfully balance } \\
\text { chemical equations }\end{array}$ & & \\
\hline $\begin{array}{l}\text { Activity 11: Reinforce } \\
\text { students' effort, persistence, } \\
\text { and effective use of learning } \\
\text { strategies to motivate } \\
\text { students to use these } \\
\text { strategies in the future. }\end{array}$ & Teacher Data & Teacher Data & $\begin{array}{l}\text { Daily logs and } \\
\text { tangible reinforcers } \\
\text { were used to show } \\
\text { growth in } 10 / 10 \\
\text { students }\end{array}$ \\
\hline $\begin{array}{l}\text { Activity 12: Leverage } \\
\text { student choice and interest } \\
\text { to boost student motivation }\end{array}$ & $\begin{array}{l}\text { 10/10 students selected } \\
\text { activities, books and }\end{array}$ & $\begin{array}{l}\text { 10/10 Students } \\
\text { complete sentence }\end{array}$ & \\
\hline
\end{tabular}




\begin{tabular}{|c|c|c|c|}
\hline and engagement. & $\begin{array}{l}\text { software based on } \\
\text { individual goal }\end{array}$ & $\begin{array}{l}\text { frames to show how } \\
\text { they grew academically }\end{array}$ & \\
\hline $\begin{array}{l}\text { Activity 13: Encourage } \\
\text { students to try new } \\
\text { academic activities at } \\
\text { appropriate instructional and } \\
\text { independent levels }\end{array}$ & Teacher Data & Teacher Data & $\begin{array}{l}10 / 10 \text { students } \\
\text { were allowed to } \\
\text { self-select activities } \\
\text { they were } \\
\text { interested in. Many } \\
\text { chose computer } \\
\text { coding using } \\
\text { Scratch or other } \\
\text { STEM activities. }\end{array}$ \\
\hline $\begin{array}{l}\text { Activity 14: Remind } \\
\text { students of recent, similar } \\
\text { successes in related subject } \\
\text { areas or tasks. }\end{array}$ & Teacher Data & Teacher Data & $\begin{array}{l}10 / 10 \text { were given } \\
\text { daily feedback } \\
\text { using the } \\
\text { assessments and } \\
\text { the WIDA Rubrics. } \\
\text { Feedback was sent } \\
\text { using the calendar } \\
\text { feature in Google. }\end{array}$ \\
\hline $\begin{array}{l}\text { Activity 15: Give frequent, } \\
\text { focused, task-specific } \\
\text { feedback to help students } \\
\text { learn what they are doing } \\
\text { correctly and how they can } \\
\text { improve }\end{array}$ & Teacher Data & Teacher Data & $\begin{array}{l}10 / 10 \text { were given } \\
\text { daily feedback } \\
\text { using the } \\
\text { assessments and } \\
\text { the WIDA Rubrics. }\end{array}$ \\
\hline $\begin{array}{l}\text { Activity 16: Capstone: } \\
\text { Create opportunities for } \\
\text { self-efficacy beliefs to } \\
\text { generalize across situations }\end{array}$ & $\begin{array}{l}10 / 10 \text { Students stated } \\
\text { their future goals and } \\
\text { created a PowerPoint } \\
\text { to show how they } \\
\text { would achieve the } \\
\text { goals. }\end{array}$ & $\begin{array}{l}10 / 10 \text { used sentence } \\
\text { frames to write their } \\
\text { future goals. }\end{array}$ & \\
\hline Activity 17: Post Test GSE & $\begin{array}{l}\text { 10/10 completed the } \\
\text { GSE }\end{array}$ & $\begin{array}{l}\text { 10/10 completed the } \\
\text { GSE }\end{array}$ & \\
\hline
\end{tabular}

\section{Limitations}

There were a few limitations to this study. One was that there was not a control group in this quasiexperimental study. All of the students who attended the class that day participated in the lesson. A second limitation was that some students provided short answers and were not able to generalize when asking for help from content teachers. Two students had difficulty using translation tools because they do not use their first language in academic settings. Two of the students were born in the US and never acquired literacy skills in their native language even though they prefer to speak that language when at home and in social settings. Many K-12 ESL teachers are faced with this challenge as to how to best meet the needs for these students. It is expected that students will have different levels of academic language in their native language and English. In some cases, the students will have more advanced English skills then they have in their native language. Finally, in the future data could be taken using a control and an experimental group. Additionally, students could be given multiple treatments, or a comparison could be made between the strategies that were presented. Another limitation was that there was no other data found where a teacher used the prescribed strategies and collected data and published the findings from the toolkit. A final limitation is that the toolkit failed to include exact lessons and only suggested strategies, so resources to teach the strategies were either found on other websites or they were developed by the teacher. This makes 
sites like Transforming Education less practitioner friendly as many educators would not want to spend time finding the materials to implement the strategies.

\section{Scholarly Significance of the Study}

Margolis \& McCabe (2006) found that teachers should regularly encourage struggling learners to try new academic activities. Teachers need to create academic activities at the appropriate instructional and independent levels, struggling learners will likely believe that moderate effort will produce success as was the case with this study. Since many emergent bilingual students are classified as struggling learners, they often require additional supports and targeted instruction.

The results of the study concluded that emergent bilingual students could increase their self-efficacy through direct instruction strategies and using peer models. The emergent bilingual students increased their ability to advocate for themselves when making requests and asking for assistance in both in class and in virtual learning environments. This current study also determined that strategies that were created for a general education setting could be adapted for emergent bilinguals enrolled in middle grades. It also allowed the students to use these skills when speaking to faculty members or when they enter the workforce in the future. As an action researcher, it is also essential to monitor and reflect on the strategies and to make changes to lessons to better meet the needs of the students.

In conclusion, the study allowed for students to show growth that will be transferred into all academic settings. Utilizing reading, writing, speaking, and listening skills will also allow the students to gain independence and to become academically successful in many content areas in the future. Many schools are promoting social emotional learning, and many should consider self-efficacy as part of these initiatives. Students who understand their learning and can ask for help will successfully navigate their academic environment and have successful outcomes.

\section{REFERENCES}

American Psychological Association. (2009). Teaching Tip Sheet-Self-Efficacy. Retrieved from https://www.apa.org/pi/aids/resources/education/self-efficacy

Bandura, A. (1977). Self-efficacy: Toward a unifying theory of behavioral change. Psychological Review, $84,191-215$.

Bandura, A. (1981). Self-referent thought: A development analysis of self-efficacy. In J.H. Flavell \& L. Ross (Eds.), Social cognitive development: Frontiers and possible futures (pp. 200-239). Cambridge, England: Cambridge University Press.

Bandura, A. (1982). Self-efficacy mechanism in human agency. American Psychologist, 37, 122-147.

Brophy, S., Klein, S., Portsmore. M., \& Rogers, C. (2008). Advancing engineering education in P-12 Classrooms. The Research Journal for Engineering Education, 97(3), 369-387.

Denton, P., \& Kriete, R. (2000). The First Six Weeks of School. Boston, MA: Northeast Foundation for Children.

Education Voices. (2016). Mindfulness in the classroom - Body Scan. Retrieved from https://educationsvoice.wordpress.com/2016/05/07/mindfulness-in-the-classroom-body-scan/

English, L.D. (2017). Advancing elementary and middle school STEM education. International Journal of Science and Math Education, 15(Suppl. 1), 5-24. https://doi.org/10.1007/s10763-017-9802-x

Flipgrid. (2020). [Computer Software] Microsoft. Retrieved from https://info.flipgrid.com/

Luszczynska, A., Scholz, U., \& Schwarzer, R. (2010). The General Self-Efficacy Scale: Multicultural Validation Studies. Journal of Psychology, 139, 439-457.

Margolis, H., \& McCabe, P.P. (2006). Improving self-efficacy and motivation what to do, what to say. Intervention in School and Clinic, 41(4), 218-227.

Military Child Education Coalition ${ }^{\circledR}\left(\right.$ MCEC) ${ }^{\circledR}$. (2013). Roadmap to Success. Retrieved from https://www.militarychild.org/upload/files/MSTC\%20MSTA/MS_Roadmaps_to_Success.pdf 
Nippold, M. (2000). Language development during the adolescent years: Aspects of pragmatics, syntax, and semantics. Topics in Language Disorders, 20(2), 15-28. doi: 10.1097/00011363-20002002000004

Schunk, D.H., \& Hanson, A.R. (1985). Peer models: Influence on children's self-efficacy and achievement. Journal of Educational Psychology, 77, 313-322.

Schwarzer, R., \& Jerusalem, M. (1995). English Version of the General Self Efficacy Scale. Retrieved from http://userpage.fu-berlin.de/ health/engscal.htm

transforming education. (n.d.). Self-Efficacy: Supplemental Handout. Retrieved from https://www.transformingeducation.org/self-efficacy-toolkit/

WIDA. (2016). Can Do Descriptors 6-8. Retrieved from https://wida.wisc.edu/sites/default/files/resource/CanDo-KeyUses-Gr-6-8.pdf

WIDA. (2020). Speaking and Writing Interpretive Rubrics. Retrieved from https://www.wida.us/get.aspx?id=2145 